\title{
Current Concepts on the Physiopathological Relevance of Dopaminergic Receptors
}

\author{
Ada Ledonne ${ }^{1}$ and Nicola B. Mercuri ${ }^{1,2 *}$ \\ ${ }^{1}$ Department of Experimental Neuroscience, Santa Lucia Foundation, Rome, Italy, ${ }^{2}$ Department of Systems Medicine, \\ University of Rome "Tor Vergata", Rome, Italy
}

Dopamine (DA) is a key neurotransmitter modulating essential functions of the central nervous system (CNS), like voluntary movement, reward, several cognitive functions and goal-oriented behaviors. The factual relevance of DAergic transmission can be well appreciated by considering that its dysfunction is recognized as a core alteration in several devastating neurological and psychiatric disorders, including Parkinson's disease (PD) and associated movement disorders, as well as, schizophrenia, bipolar disorder, attention deficit hyperactivity disorder (ADHD) and addiction. Here we present an overview of the current knowledge on the involvement of DAergic receptors in the regulation of key physiological brain activities, and the consequences of their dysfunctions in brain disorders such as PD, schizophrenia and addiction.

Keywords: dopamine, DAergic receptors, nigrostriatal pathway, mesolimbic pathway, mesocortical pathway

\section{INTRODUCTION}

\section{OPEN ACCESS}

Edited by:

Hansen Wang,

University of Toronto, Canada

Reviewed by:

John J. Woodward,

Medical University of South Carolina,

USA

Carl Richard Lupica, National Institute on Drug Abuse (NIH), USA

Ana João Rodrigues, University of Minho, Portugal

*Correspondence:

Nicola B. Mercuri mercurin@med.uniroma2.it

Received: 24 October 2016 Accepted: 30 January 2017 Published: 08 February 2017

Citation:

Ledonne $A$ and Mercuri NB (2017) Current Concepts on the Physiopathological Relevance of Dopaminergic Receptors.

Front. Cell. Neurosci. 11:27. doi: 10.3389/fncel.2017.00027
Dopamine (DA) regulates important physiological brain's functions, including locomotion, reward and cognition, through different DAergic pathways, mainly originating in two mesencephalic nuclei, the ventral tegmental area (VTA) and the substantia nigra pars compacta (SNpc; Dahlström and Fuxe, 1964). DAergic neurons of the VTA project to limbic areas (nucleus accumbens (NAc), hippocampus and amygdala) and cortical regions, thus composing the mesolimbic- and mesocortical pathways, respectively, those of the SNpc constitute the nigrostriatal pathway mainly projecting to the dorsal striatum.

According to a traditional belief, the different DAergic pathways mediate specific physiological functions, with the nigrostriatal pathway involved in locomotion, and the mesolimbic/mesocortical pathways implicated in reward and cognition. The evidence that Parkinson's disease (PD), a disorder mainly characterized by motor inabilities, is primarily due to a dysfunction of nigrostriatal pathway, whereas neuropsychiatric disorders, like schizophrenia and addiction, involve a major dysregulation of mesolimbic/mesocortical pathways, reinforces the hypothesis of a functional segregation of DAergic pathways. Nowadays, however, this functional/physiopathological subdivision is outdated, since a key role of the nigrostriatal pathway has been recognized in cognitive functions (Haber, 2014), in reward, craving and aversion (Wise, 2009), and in schizophrenia (Perez-Costas et al., 2010; Yoon et al., 2013; Weinstein et al., 2017).

\section{DAergic RECEPTORS}

\section{Classification, Signaling and Regulatory Mechanisms}

DA-induced effects are mediated by five G protein-coupled receptors (GPCR), classified into two subclasses: the D1R-like and D2R-like receptor families. D1R-like receptors (D1R and D5R) are coupled to $\mathrm{G}_{\mathrm{s} / \mathrm{olf}}$ proteins and stimulate adenylate cyclase (AC), with production of cyclic adenosine monophosphate (cAMP) and activation of cAMP-dependent 
pathways, mainly including protein kinase A (PKA) and other downstream signals. D1R modulate different ionic channels, including voltage-activated $\mathrm{Na}^{+}-\left(\mathrm{Na}_{\mathrm{V}}\right), \mathrm{K}^{+}-\left(\mathrm{K}_{\mathrm{V}}\right)$ and $\mathrm{Ca}^{2+}$ $\left(\mathrm{Ca}_{\mathrm{v}}\right)$ channels, $\mathrm{Ca}^{2+}$-activated $\mathrm{K}^{+}-\left(\mathrm{K}_{\mathrm{Ca}}\right)$ and $\mathrm{G}$-protein gated inwardly rectifying $\mathrm{K}^{+}$(GIRK) channels (Maurice et al., 2001; Witkowski et al., 2008; Yang et al., 2013). D2R-like receptors (D2R, D3R and D4R), by coupling to $G_{i / o}$ proteins, induce inhibition of AC and PKA-dependent pathways, as well as activation of GIRK and closure of $\mathrm{Ca}_{\mathrm{V}}$ (Missale et al., 1998) (Figure 1).

D2R-like receptors genes generate variants. D2R exists in two functional isoforms, D2 long (D2L) and D2 short (D2S; Giros et al., 1989), whereas several D3R isoforms have been identified (Giros et al., 1991). Multiple D4R variants are produced, mostly having a domain repeated 2 (2R), 4 (4R) and 7 (7R) times (Van Tol et al., 1992).

In addition to act as monomers, DAergic receptors constitute dimeric and/or oligomeric complexes by association of different subtypes either alone or with other GPCRs and ligand-gated channels. Homodimers exist, like D1R-D2R, D2R-D4R, D1R-D3R, D2R-D3R and D2R-D5R, as well as oligomeric complexes containing DAergic receptors associated to the adenosine $\mathrm{A} 1$ and $\mathrm{A} 2$, serotoninergic $5-\mathrm{HT}_{2 \mathrm{~A}}$, histaminergic $\mathrm{H} 3$, glutamatergic mGlu5 and NMDA receptors (Perreault et al., 2014). Dimeric/oligomeric complexes increase the complexity of DA-mediated effects, since they may display pharmacological/functional properties distinct from their constituent receptors. Indeed, D1R-D2R are linked to $G_{q / 11}$ proteins, thus modulating phospholipase C (PLC), which produces inositol trisphosphate $\left(\mathrm{IP}_{3}\right)$ and diacylglycerol (DAG) to regulate intracellular $\mathrm{Ca}^{2+}$ (Lee et al., 2004) (Figure 1).
While the prevailing belief is that DAergic receptors act through $G$ proteins, they can also activate $G$ proteinsindependent mechanisms. A role in the $G$ protein-independent signaling is played by arrestins, multifunctional adaptor proteins, which bind DAergic receptors phosphorylated by GPCR kinases (GRKs; Gainetdinov et al., 2004). Binding of arrestins recruits several proteins, including Akt, GSK-3, MAPK, c-Src, $\mathrm{Mdm} 2$ and $\mathrm{N}$-ethylmaleimide-sensitive factor, thus greatly enhancing DA-activated pathways (Beaulieu and Gainetdinov, 2011) (Figure 1).

GRKs also regulate DAergic receptors by mediating their desensitization, since their phosphorylation elicits receptor's endocytosis. GRK2, GRK3, GRK4, GRK5 and GRK6 regulate D1R and D2R (Tiberi et al., 1996; Ito et al., 1999; Watanabe et al., 2002; Villar et al., 2009), whereas GRK4 controls D3R (Villar et al., 2009).

Besides GRKs, the regulators of G protein signaling (RGS), a group of GTPase-activating proteins acting on $G$ protein, negatively modulate DAergic receptors. Among RGS members, RGS9-2 affects D2R (Cabrera-Vera et al., 2004), RGS4 modulates D2R, D1R/D3R (Min et al., 2012) and D2R/A2A (Lerner and Kreitzer, 2012), whereas R7 subgroup regulate D2R (Wani et al., 2012).

\section{PHYSIOLOGICAL FUNCTIONS OF DAergic RECEPTORS}

\section{Control of Locomotion}

The regulation of locomotion represents a well-characterized function of DAergic receptors. Thus, DA in the dorsal striatum modulates basal ganglia activity, by DAergic receptors mainly

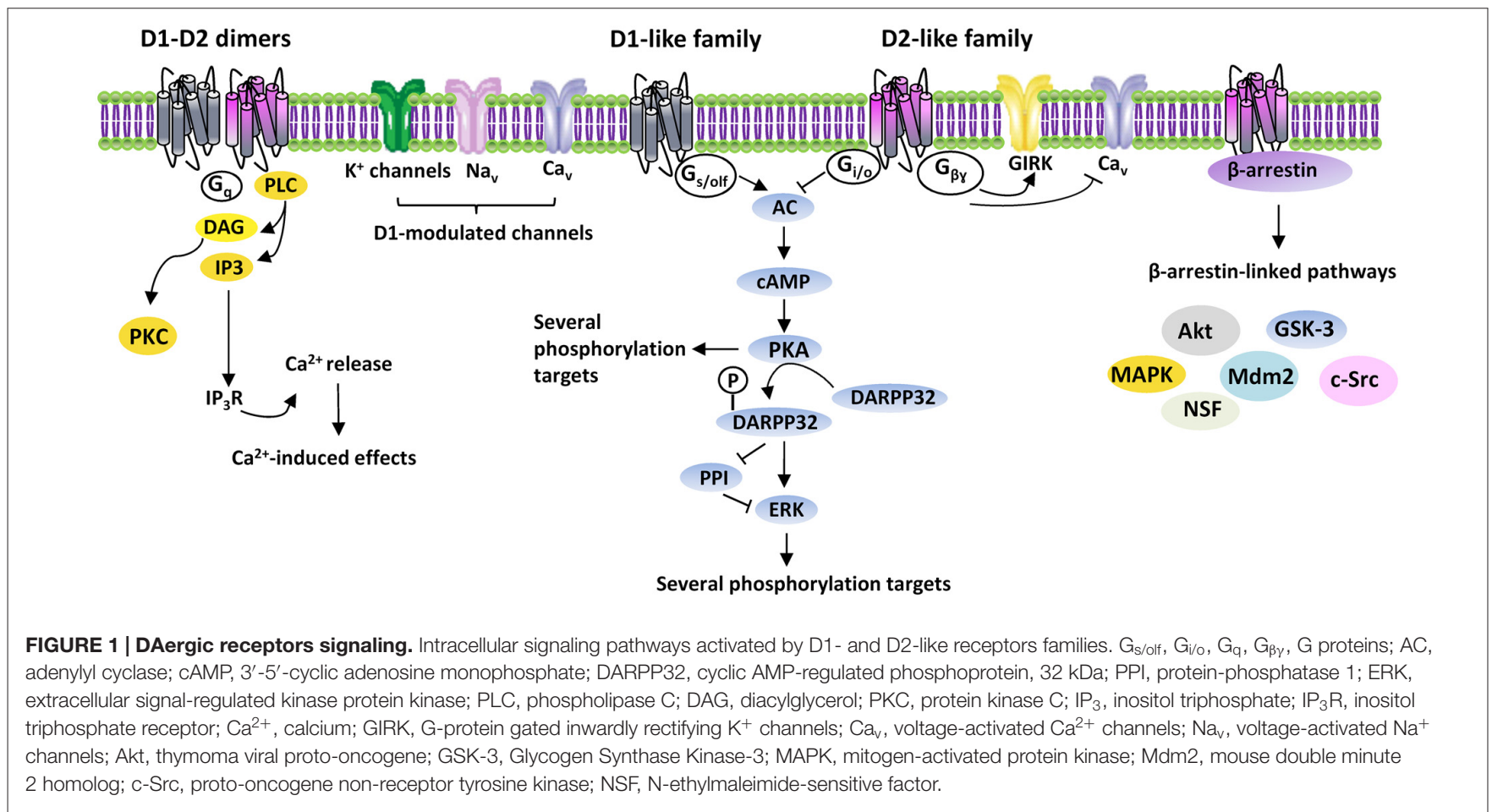


expressed on GABAergic medium spiny neurons (MSNs). D1R and D2R principally display a segregated expression on striatal MSNs (Gerfen and Surmeier, 2011). D1R-expressing MSNs directly project to basal ganglia's output nuclei, the substantia nigra pars reticulata (SNpr) and the globus pallidus internus (GPi; direct pathway). D2R-expressing MSNs project to intermediate nuclei, the external globus pallidus (GPe) that projects to the subthalamic nucleus (STN; indirect pathway). The combined D1R/D2R activation regulates SNpr/GPi, which control the excitation of the cortex via thalamus, thus promoting/inhibiting locomotion. An opposite role of D1Rand D2R-expressing neurons on movement has been recently confirmed, since the stimulation of direct pathway facilitates movement, while the activation of indirect pathway causes hypokinesia (Kravitz et al., 2010). However, the evidence that $\mathrm{D} 1 \mathrm{R} / \mathrm{D} 2 \mathrm{R}$ is co-expressed in a small subgroup of MSNs (Aizman et al., 2000) adds complexity to their roles in movement.

Striatal DA effects are regulated by D2R autoreceptors, localized presynaptically on DAergic terminals and mesencephalic cells. Thus, D2R provide a negative feedback, which by tuning neuronal firing and DA synthesis/release, changes extracellular neurotransmitter level (Lacey et al., 1987; Wolf and Roth, 1990). D3R, possibly as D2R/D3R, could also act as inhibitory autoreceptors (De Mei et al., 2009; but see Mercuri et al., 1997). Accordingly to an important role of D2R in movement regulation, the constitutive deletion of all D2R (Kelly et al., 1998) or D2L isoforms (Usiello et al., 2000; Wang et al., 2000), as well as D2R deletion in adulthood (Bello et al., 2016) impairs spontaneous and agonists-stimulated locomotion. Interestingly, D2R on striatal cholinergic interneurons are involved in catalexia induced by neuroleptics (D2 antagonists; Kharkwal et al., 2016).

Specific DA-activated pathways, such as MEK/ERK, GSK3 $\beta$ and $\mathrm{mTOR}$, have been implicated in locomotion (Beaulieu et al., 2005, 2007; Santini et al., 2007; Urs et al., 2011). Moreover, GRK2 might regulate locomotion, since GRK2 KO mice display altered movements associated with DAergic dysfunctions (Daigle et al., 2014).

Therefore, a proper locomotion depends on MSNs D1R and D2R function. While D2R and D3R autoreceptors mainly regulate DA extracellular levels, D4R and D5R subtypes are dispensable for DA-induced regulation of locomotion (Missale et al., 1998).

\section{Reward}

The mesolimbic DAergic pathway plays a central role in the processing of reward-related stimuli, which mainly increase extracellular DA levels in the NAc (Di Chiara, 2002; Volkow and Morales, 2015). Additionally, the nigrostriatal pathway also mediates reward processing (Wise, 2009). DAergic transmission contributes to the reward prediction signal, since DAergic neuronal firing enhances following unexpected/novel rewards and is inhibited if an expected reward does not materialize (Schultz et al., 1997; Schultz, 2002).

D1R or D2R either are involved in reward induced by natural stimuli (food, sex) or addictive drugs. In the NAc,
$\mathrm{D} 1 \mathrm{R}$ and D2R are largely compartmentalized on MSNs of the direct/indirect pathways, respectively (Gerfen et al., 1990). It is believed that direct/indirect pathways have different roles in reward, with the direct pathway mediating reward while the indirect one encoding aversion (Hikida et al., 2010; Kravitz et al., 2012). Thus, D1R-dependent stimulation of the direct pathway causes reward, whereas D2R-induced inhibition of indirect pathway opposes aversion and facilitates reward (Hikida et al., 2013). Actually, accumbal D1R activation is sufficient to produce reward (Caine et al., 2002), while a combined D1R/D2R activation causes maximal reward (Steinberg et al., 2014). However, the co-expression of $\mathrm{D} 1 \mathrm{R} / \mathrm{D} 2 \mathrm{R}$ on a subpopulation of MSNs (Perreault et al., 2012) renders the functions of $\mathrm{D} 1 \mathrm{R} / \mathrm{D} 2 \mathrm{R}$ on direct/indirect pathways more complex than is usually thought.

D3R seem less involved in reward processing, but rather affect addictive behaviors (Sokoloff and Le Foll, 2017). Contrasting evidence exist about a role for D4R in reward (Di Ciano et al., 2014), although genetic association studies found correlations between D4R variants and addictive behaviors (Ptáček et al., 2011). D5R are not involved in reward.

\section{Regulation of Cognitive Functions}

DA regulates essential cognitive functions through DAergic receptors expressed in the prefrontal cortex (PFC), striatum and hippocampus. However, the role of DA in cognition appears rather complex and poorly elucidated at cellular level, with DAergic receptors controlling ionic conductances and/or synaptic plasticity on different neuronal populations (Floresco and Magyar, 2006; Arnsten et al., 2015).

D1R-like receptors modulate several aspects of cognition. D1R are highly expressed in PFC and striatum and moderately in hippocampus, whereas D5R display a similar distribution with lower levels. Thus, D1R family control working memory, behavioral flexibility, decision-making and goal-directed behaviors (Sawaguchi and Goldman-Rakic, 1991; Ragozzino, 2002; Floresco et al., 2006), as well as hippocampal-dependent learning and memory (Packard and White, 1991; Bach et al., 1999; El-Ghundi et al., 1999; Hansen and Manahan-Vaughan, 2014). D1R/D5R regulate cortical pyramidal neurons excitability and recurrent excitations within neuronal networks (Seamans and Yang, 2004) underlying executive functions, besides controlling synaptic plasticity in striatum and hippocampus (Calabresi et al., 1992b; Kerr and Wickens, 2001; Hansen and Manahan-Vaughan, 2014).

D2R are highly expressed in striatum and hippocampus and moderately in layer 5 of PFC and regulate behavioral flexibility, goal-directed behaviors and decision-making, also affecting working- and long-term memory (Ragozzino, 2002; Floresco et al., 2006; Stelzel et al., 2013; Puig and Miller, 2015). D2R-activated mechanisms modify cortical pyramidal neurons excitability (Gulledge and Jaffe, 1998; Wang and Goldman-Rakic, 2004), and/or glutamatergic synaptic plasticity in striatum and hippocampus (Calabresi et al., 1992b; Rocchetti et al., 2015; Broussard et al., 2016).

Despite D3R are almost absent in PFC, they indirectly modulate PFC-dependent cognitive functions, by inhibiting 
mesocortical DAergic activity and/or adjusting cortical Ach levels (Loiseau and Millan, 2009; Gross and Drescher, 2012). Thus, D3R inhibition improves attention, learning, memory and executive functions (Nakajima et al., 2013), whereas striatal D3R modulate behavioral flexibility (Groman et al., 2016).

D4R in PFC and hippocampus affect different cognitive tasks, including inhibitory avoidance and object recognition memory (Bernaerts and Tirelli, 2003; Powell et al., 2003; Woolley et al., 2008), being also involved in attention and exploratory behavior (Oak et al., 2000).

\section{DAergic TRANSMISSION IN BRAIN DISORDERS}

\section{Parkinson's Disease (PD)}

The progressive neurodegeneration of SNpc DAergic neurons represents the core feature of $\mathrm{PD}$, a neurological disorder mainly characterized by severe motor inabilities. Indeed, striatal DAergic denervation unbalances the activation rate of direct/indirect pathways of basal ganglia, thus causing deficits in movement initiations, rigidity and bradykinesia. In PD there is a reorganization of DAergic receptors in basal ganglia (Albin et al., 1989), being D2R expression increased in MSNs-indirect pathway and D1R mRNAs reduced in MSNs-direct pathway (Gerfen et al., 1990). Moreover, the SNpc neurons degeneration leads to progressive loss of D2R on striatal presynaptic terminals. Meanwhile, as a compensation, DAergic receptors become supersensitive, possibly depending on a more effective $G$ protein-receptors coupling and/or an increased expression of signaling proteins (Hornykiewicz, 2001; Napolitano et al., 2002). Supersensitivity has been reported for striatal D1R and D2R, particularly, in striato-pallidal/striato-nigral terminals (Corvol et al., 2004; Guigoni et al., 2007; Prieto et al., 2011). Accordingly, in PD animal models, the D1R-dependent regulation of direct pathway enhances nigral GABA release (Mango et al., 2014a).

Noteworthy, DAergic receptors supersensitivity could represent the biological substrate underlying motor abnormalities produced by prolonged treatments with the DA precursor, L-DOPA. Its administration often causes motor fluctuations and involuntary movements, namely L-DOPAinduced dyskinesia (LID). Striatal D1R hyperactivation plays a pivotal role in LID development (Cenci, 2007). Indeed, in LID animal models, D1R-linked signaling is hyperactive, with increased cAMP levels and higher phosphorylation of ERK1/2, DARPP-32 and mTOR (Greengard et al., 1999; Picconi et al., 2003; Aubert et al., 2005; Pavón et al., 2006; Santini et al., 2007). Accordingly, strategies reducing D1R functions significantly rescue motor abnormalities in LID models (Fiorentini et al., 2016). Moreover, based on D1R-A1R expression on striatal MSNs, the A1R modulation, by counteracting excessive $\mathrm{D} 1 \mathrm{R}$ signaling in $\mathrm{PD}$, reduces L-DOPA-induced involuntary movements (Mango et al., 2014b).

A dysfunctional RGS-dependent modulation of DAergic receptors could contribute to motor disorders. Indeed, RGS9-2 plays a role in the occurrence of motor anomalies in LID, since RGS9-2 KO mice develop dyskinesia associated with D2R dysfunctions, and RGS9-2 overexpression diminishes L-DOPA-induced involuntary movements (Kovoor et al., 2005; Gold et al., 2007).

\section{Addiction}

Addiction is a neuropsychiatric disorder characterized by compulsive engagement in rewarding stimuli, despite adverse consequences. It is considered dependent on complex neuronal modifications induced by transcriptional/epigenetic mechanisms following repeated exposure to reinforcing stimuli, based on a psychobiological vulnerability (Volkow and Morales, 2015).

There are established associations between polymorphisms in DAergic receptors genes and addiction, with genetic variants of D1R, D2R, D3R and D4R linked to substance abuse, alcoholism, bulimia nervosa and pathological gambling (Blum et al., 1995; Comings et al., 1999; da Silva Lobo et al., 2007; Le Foll et al., 2009; Ptáčk et al., 2011).

Modifications in the mesolimbic/mesocortical DAergic pathways represent core biological changes underlying addictive behaviors. Synthetic/natural rewards increase extracellular DA in limbic/cortical areas, besides producing other long-term modifications, including a potentiation of glutamatergic transmission in midbrain DAergic nuclei, NAc, striatum and cortex (Volkow and Morales, 2015). Moreover, long-term changes in DAergic receptor responsiveness possibly contribute to synaptic/neuronal adaptations leading to psychostimulant-induced sensitization and compulsion (Hyman et al., 2006). Actually, addictive drugs downregulate $\mathrm{D} 2 \mathrm{R}$-like receptors, with a reduced expression of striatal D2R and D3R in individuals addicted to cocaine, methamphetamine, alcohol or heroin (Volkow et al., 1993, 1996, 2001).

Although modifications in D1R expression have not been consistently demonstrated in addiction (Martinez et al., 2009), D1R play a prominent role in the acquisition/maintenance of self-administration behavior (Self, 2010). Thus, pharmacological/genetic D1R inhibition reduces the sensitivity to rewarding effects of psychostimulants and impairs cocaine self-administration (Caine et al., 1995, 2007).

$\mathrm{D} 2 \mathrm{R}$ in midbrain DA neurons are also involved in the establishment of addictive behaviors, since D2R deletion enhances food intake and sensitivity to locomotor/rewarding properties of cocaine (Bello et al., 2011). Accordingly, drug intake and impulsivity are inversely correlated with D2R availability in SNpc/VTA (Buckholtz et al., 2010).

Modifications in RGS proteins affecting D2R may play a role in addiction. Psychostimulants and D2R ligands exposure alter RGS9-2 protein levels (Seeman et al., 2007), whereas amphetamine self-administration increases RGS2/RGS4 mRNAs expression in VTA/NAc, but reduces D2RS mRNAs levels in VTA (Sun et al., 2015). Moreover, RGS9-2 deletion exacerbates the rewarding/motor effects of psychostimulants, which are instead counteracted by RGS9-2 overexpression (Rahman et al., 2003; Traynor et al., 2009).

D3R do not directly control the reinforcing/psychomotor effects of psychostimulants (Reavill et al., 2000; Caine et al., 
2002), although a D3R deletion increases the sensitivity to cocaine and amphetamine (Xu, 1998). D3R affect cue-induced drug-seeking behaviors and relapse (Sokoloff and Le Foll, 2017), thus D3R antagonists might represent potential therapeutics for drug addiction.

$\mathrm{D} 4 \mathrm{R}$ is considered a minor player in mediating psychostimulants-induced reinforce (Costanza and Terry, 1998; Caine et al., 2002). D4R null mice appear more sensitive to locomotor, but not rewarding, properties of addictive drugs (Rubinstein et al., 1997; Thanos et al., 2010). Notwithstanding, $D 4 R$ represents a susceptibility gene for food/drug dependence and pathological gambling (Comings et al., 1999; Ptáček et al., 2011; Silveira et al., 2014). D4R are involved in relapse, thus their inhibition has been proposed as a potential strategy for addiction (Di Ciano et al., 2014).

\section{Schizophrenia}

The "DA theory" for a dysfunction of DAergic transmission represents the first pathogenetic hypothesis of psychosis, being postulated following the fortuitous discovery of antipsychotics, acting as D2R antagonists. Actually, a hyperactivation of DAergic mesencephalic nuclei associated to a DAergic hypofunction in PFC have been demonstrated in schizophrenia (Howes and Kapur, 2009; Perez-Costas et al., 2010; Yoon et al., 2013; Weinstein et al., 2017). Besides DAergic dysfunctions, alterations in glutamatergic transmission occur, with the "DA-Glutamate hypothesis" representing the current pathogenetic theory for schizophrenia (Laruelle et al., 2003).

Supersensitivity to DA, due to modified DAergic receptors expression and/or functions, might contribute to schizophrenic symptomatology (Seeman et al., 2005).

Evidence regarding modifications in D1R expression in schizophrenia are contrasting, reporting either decreased (Okubo et al., 1997; Friedman et al., 1999) or increased levels (AbiDargham et al., 2002, 2012). However, hypostimulation of cortical D1R likely contributes to cognitive/negative symptoms (Abi-Dargham and Moore, 2003).

Some studies have highlighted altered D2R expression (Frankle and Laruelle, 2002; Nikolaus et al., 2009), with a specific increase in high-affinity D2R (D2RH) possibly mediating DA supersensitivity underlying psychosis (Seeman, 2011).

\section{REFERENCES}

Abi-Dargham, A., Mawlawi, O., Lombardo, I., Gil, R., Martinez, D., Huang, Y., et al. (2002). Prefrontal dopamine D1 receptors and working memory in schizophrenia. J. Neurosci. 22, 3708-3719.

Abi-Dargham, A., and Moore, H. (2003). Prefrontal DA transmission at D1 receptors and the pathology of schizophrenia. Neuroscientist 9, 404-416. doi: $10.1177 / 1073858403252674$

Abi-Dargham, A., Xu, X., Thompson, J. L., Gil, R., Kegeles, L. S., Urban, N., et al. (2012). Increased prefrontal cortical $D_{1}$ receptors in drug naive patients with schizophrenia: a PET study with $\left[{ }^{11} \mathrm{C}\right]$ NNC112. J. Psychopharmacol. 26, 794-805. doi: 10.1177/02698811114 09265

Aizman, O., Brismar, H., Uhlén, P., Zettergren, E., Levey, A. I., Forssberg, H., et al. (2000). Anatomical and physiological evidence for D1 and D2 dopamine receptor colocalization in neostriatal neurons. Nat. Neurosci. 3, 226-230. doi: $10.1038 / 72929$
Nevertheless, other evidence refutes modified D2R expression, supporting the idea that the alterations detected in patients represent a compensation to prolonged D2R antagonism with antipsychotics (Calabresi et al., 1992a; Weinstein et al., 2017).

Dysfunctions in the $\mathrm{D} 2 \mathrm{R}-\beta$-arrestin interaction and in $\beta$-arrestin-dependent modulation of Akt/GSK3 pathway might be involved in schizophrenia (Beaulieu et al., 2009). Actually, drugs affecting D2R/ $\beta$-arrestin interaction demonstrate antipsychotic effects in animal models of schizophrenia (Park et al., 2016), revealing alternative therapeutic strategies, downstream to D2R.

In light of their restricted localization in limbic areas, D3R has been proposed as a valuable target for schizophrenia treatment (Gurevich et al., 1997). D3R modulation could improve cognitive/negative schizophrenic symptoms, without producing extrapyramidal/motor effects as D2R antagonists (Joyce and Millan, 2005). Actually, novel antipsychotics acting as D3R partial agonists/antagonists, ameliorate cognitive/negative schizophrenic symptoms (Leggio et al., 2016).

$\mathrm{D} 4 \mathrm{R}$ also received interest as targets for schizophrenia's treatment, since the atypical antipsychotic, clozapine, mainly acts as D4R antagonist. Moreover, increased cortical D4R levels (Seeman et al., 1993) and D4R genetic variations have been associated to schizophrenia (Hwu et al., 1998; Ptácek et al., 2011).

\section{CONCLUSION}

DAergic receptors play key roles in physiological brain functioning, since they regulate locomotion, reward, cognitive functions and goal-oriented behaviors. Modifications in DAergic receptors expression and signaling occur in different neurological and neuropsychiatric disorders. While modulators of DAergic receptors already represent valuable drugs for the symptomatic treatment of PD and schizophrenia, an in-depth understanding of DAergic dysfunctions might lead to identify novel biological targets to profoundly change the fate of DA-related neurological and psychiatric conditions.

\section{AUTHOR CONTRIBUTIONS}

$\mathrm{AL}$ and NBM equally contribute in writing the article.

Albin, R. L., Young, A. B., and Penney, J. B. (1989). The functional anatomy of basal ganglia disorders. Trends Neurosci. 12, 366-375. doi: 10.1016/01662236(89)90074-X

Arnsten, A. F., Wang, M., and Paspalas, C. D. (2015). Dopamine's actions in primate prefrontal cortex: challenges for treating cognitive disorders. Pharmacol. Rev. 67, 681-696. doi: 10.1124/pr.115.010512

Aubert, I., Guigoni, C., Håkansson, K., Li, Q., Dovero, S., Barthe, N., et al. (2005). Increased D1 dopamine receptor signaling in levodopa-induced dyskinesia. Ann. Neurol. 57, 17-26. doi: 10.1002/ana.20296

Bach, M. E., Barad, M., Son, H., Zhuo, M., Lu, Y.-F., Shih, R., et al. (1999). Agerelated defects in spatial memory are correlated with defects in the late phase of hippocampal long-term potentiation in vitro and are attenuated by drugs that enhance the cAMP signalling pathway. Proc. Natl. Acad. Sci. U S A 96, 5280-5285. doi: 10.1073/pnas.96.9.5280

Beaulieu, J. M., and Gainetdinov, R. R. (2011). The physiology, signaling, and pharmacology of dopamine receptors. Pharmacol. Rev. 63, 182-217. doi: $10.1124 /$ pr.110.002642 
Beaulieu, J. M., Gainetdinov, R. R., and Caron, M. G. (2009). Akt/GSK3 signaling in the action of psychotropic drugs. Annu. Rev. Pharmacol. Toxicol. 49, 327-347. doi: 10.1146/annurev.pharmtox.011008.145634

Beaulieu, J. M., Sotnikova, T. D., Marion, S., Lefkowitz, R. J., Gainetdinov, R. R., and Caron, M. G. (2005). An Akt/ $\beta$-arrestin 2/PP2A signaling complex mediates dopaminergic neurotransmission and behavior. Cell 122, 261-273. doi: $10.1016 /$ j.cell.2005.05.012

Beaulieu, J. M., Tirotta, E., Sotnikova, T. D., Masri, B., Salahpour, A., Gainetdinov, R. R., et al. (2007). Regulation of Akt signaling by D2 and D3 dopamine receptors in vivo. J. Neurosci. 27, 881-885. doi: 10.1523/jneurosci. 5074-06.2007

Bello, E. P., Casas-Cordero, R., Galiñanes, G. L., Casey, E., Belluscio, M. A., Rodríguez, V., et al. (2016). Inducible ablation of dopamine D2 receptors in adult mice impairs locomotion, motor skill learning and leads to severe parkinsonism. Mol. Psychiatry doi: 10.1038/mp.2016.105 [Epub ahead of print].

Bello, E. P., Mateo, Y., Gelman, D. M., Noaín, D., Shin, J. H., Low, M. J., et al. (2011). Cocaine supersensitivity and enhanced motivation for reward in mice lacking dopamine D2 autoreceptors. Nat. Neurosci. 14, 1033-1038. doi: $10.1038 / \mathrm{nn} .2862$

Bernaerts, P., and Tirelli, E. (2003). Facilitatory effect of the dopamine D4 receptor agonist PD168,077 on memory consolidation of an inhibitory avoidance learned response in C57BL/6J mice. Behav. Brain Res. 142, 41-52. doi: 10.1016/s0166-4328(02)00371-6

Blum, K., Sheridan, P. J., Wood, R. C., Braverman, E. R., Chen, T. J., and Comings, D. E. (1995). Dopamine D2 receptor gene variants: association and linkage studies in impulsive-addictive-compulsive behaviour. Pharmacogenetics 5, 121-141. doi: 10.1097/00008571-199506000-00001

Broussard, J. I., Yang, K., Levine, A. T., Tsetsenis, T., Jenson, D., Cao, F., et al. (2016). Dopamine regulates aversive contextual learning and associated in vivo synaptic plasticity in the hippocampus. Cell Rep. 14, 1930-1939. doi: 10.1016/j. celrep.2016.01.070

Buckholtz, J. W., Treadway, M. T., Cowan, R. L., Woodward, N. D., Li, R., Ansari, M. S., et al. (2010). Dopaminergic network differences in human impulsivity. Science 329:532. doi: 10.1126/science.1185778

Cabrera-Vera, T. M., Hernandez, S., Earls, L. R., Medkova, M., SundgrenAndersson, A. K., Surmeier, D. J., et al. (2004). RGS9-2 modulates D2 dopamine receptor-mediated $\mathrm{Ca}^{2+}$ channel inhibition in rat striatal cholinergic interneurons. Proc. Natl. Acad. Sci. U S A 101, 16339-16344. doi: $10.1073 /$ pnas.0407416101

Caine, S. B., Heinrichs, S. C., Coffin, V. L., and Koob, G. F. (1995). Effects of the dopamine D-1 antagonist SCH 23390 microinjected into the accumbens, amygdala or striatum on cocaine self-administration in the rat. Brain Res. 692, 47-56. doi: 10.1016/0006-8993(95)00598-k

Caine, S. B., Negus, S. S., Mello, N. K., Patel, S., Bristow, L., Kulagowski, J., et al. (2002). Role of dopamine D2-like receptors in cocaine self-administration: studies with D2 receptor mutant mice and novel D2 receptor antagonists. J. Neurosci. 22, 2977-2988.

Caine, S. B., Thomsen, M., Gabriel, K. I., Berkowitz, J. S., Gold, L. H., Koob, G. F., et al. (2007). Lack of self-administration of cocaine in dopamine D1 receptor knock-out mice. J. Neurosci. 27, 13140-13150. doi: 10.1523/JNEUROSCI.228407.2007

Calabresi, P., De Murtas, M., Mercuri, N. B., and Bernardi, G. (1992a). Chronic neuroleptic treatment: D2 dopamine receptor supersensitivity and striatal glutamatergic transmission. Ann. Neurol. 31, 366-373. doi: 10.1002/ana. 410310404

Calabresi, P., Maj, R., Mercuri, N. B., and Bernardi, G. (1992b). Coactivation of $\mathrm{D} 1$ and D2 dopamine receptors is required for long-term synaptic depression in the striatum. Neurosci. Lett 142, 95-99. doi: 10.1016/0304-3940(92)90628-k

Cenci, M. A. (2007). L-DOPA-induced dyskinesia: cellular mechanisms and approaches to treatment. Parkinsonism Relat. Disord. 13, S263-S267. doi: 10.1016/s1353-8020(08)70014-2

Di Chiara, G. (2002). Nucleus accumbens shell and core dopamine: differential role in behavior and addiction. Behav. Brain Res. 137, 75-114. doi: 10.1016/s0166-4328(02)00286-3

Di Ciano, P., Grandy, D. K., and Le Foll, B. (2014). Dopamine D4 receptors in psychostimulant addiction. Adv. Pharmacol. 69, 301-321. doi: 10.1016/B9780-12-420118-7.00008-1

Comings, D. E., Gonzalez, N., Wu, S., Gade, R., Muhleman, D., Saucier, G., et al. (1999). Studies of the 48 bp repeat polymorphism of the DRD4 gene in impulsive, compulsive, addictive behaviors: tourette syndrome, ADHD, pathological gambling, and substance abuse. Am. J. Med. Genet. 88, 358-368. doi: 10.1002/(SICI)1096-8628(19990820)88:4<358::AID-AJMG13>3.0.CO;2-G

Corvol, J. C., Muriel, M. P., Valjent, E., Féger, J., Hanoun, N., Girault, J. A., et al. (2004). Persistent increase in olfactory type G-protein $\alpha$ subunit levels may underlie D1 receptor functional hypersensitivity in Parkinson disease. J. Neurosci. 24, 7007-7014. doi: 10.1523/JNEUROSCI.067604.2004

Costanza, R. M., and Terry, P. (1998). The dopamine D4 receptor antagonist L-745,870: effects in rats discriminating cocaine from saline. Eur. J. Pharmacol. 345, 129-132. doi: 10.1016/s0014-2999(97)01603-8

Dahlström, A., and Fuxe, K. (1964). Localization of monoamines in the lower brain stem. Experientia 20, 398-399. doi: 10.1007/bf02147990

Daigle, T. L., Ferris, M. J., Gainetdinov, R. R., Sotnikova, T. D., Urs, N. M., Jones, S. R., et al. (2014). Selective deletion of GRK2 alters psychostimulant-induced behaviors and dopamine neurotransmission. Neuropsychopharmacology 39, 2450-2462. doi: 10.1038/npp.2014.97

El-Ghundi, M., Fletcher, P. J., Drago, J., Sibley, D. R., O'Dowd, B. F., and George, S. R. (1999). Spatial learning deficit in dopamine $D(1)$ receptor knockout mice. Eur. J. Pharmacol. 383, 95-106. doi: 10.1016/s00142999(99)00573-7

Fiorentini, C., Savoia, P., Savoldi, D., Bono, F., Busi, C., Barbon, A., et al. (2016). Shp-2 knockdown prevents L-dopa-induced dyskinesia in a rat model of Parkinson's disease. Mov. Disord. 31, 512-520. doi: 10.1002/mds.26581

Floresco, S. B., and Magyar, O. (2006). Mesocortical dopamine modulation of executive functions: beyond working memory. Psychopharmacology 188, 567-585. doi: 10.1007/s00213-006-0404-5

Floresco, S. B., Magyar, O., Ghods-Sharifi, S., Vexelman, C., and Tse, M. T. (2006). Multiple dopamine receptor subtypes in the medial prefrontal cortex of the rat regulate set-shifting. Neuropsychopharmacology 31, 297-309. doi: 10.1038/sj. npp. 1300825

Le Foll, B., Gallo, A., Le Strat, Y., Lu, L., and Gorwood, P. (2009). Genetics of dopamine receptors and drug addiction: a comprehensive review. Behav. Pharmacol. 20, 1-17. doi: 10.1097/fbp.0b013e3283242f05

Frankle, W. G., and Laruelle, M. (2002). Neuroreceptor imaging in psychiatric disorders. Ann. Nucl. Med. 16, 437-446. doi: 10.1007/bf029 88639

Friedman, J. I., Temporini, H., and Davis, K. L. (1999). Pharmacologic strategies for augmenting cognitive performance in schizophrenia. Biol. Psychiatry 45 , 1-16. doi: 10.1016/s0006-3223(98)00287-x

Gainetdinov, R. R., Premont, R. T., Bohn, L. M., Lefkowitz, R. J., and Caron, M. G. (2004). Desensitization of G protein-coupled receptors and neuronal functions. Annu. Rev. Neurosci. 27, 107-144. doi: 10.1146/annurev.neuro.27.070203. 144206

Gerfen, C. R., Engber, T. M., Mahan, L. C., Susel, Z., Chase, T. N., Monsma, F. J., et al. (1990). D1 and D2 dopamine receptor-regulated gene expression of striatonigral and striatopallidal neurons. Science 250, 1429-1432. doi: $10.1126 /$ science. 2147780

Gerfen, C. R., and Surmeier, D. J. (2011). Modulation of striatal projection systems by dopamine. Annu. Rev. Neurosci. 34, 441-466. doi: 10.1146/annurev-neuro061010-113641

Giros, B., Martres, M. P., Pilon, C., Sokoloff, P., and Schwartz, J. C. (1991). Shorter variants of the D3 dopamine receptor produced through various patterns of alternative splicing. Biochem. Biophys. Res. Commun. 176, 1584-1592. doi: 10.1016/0006-291x(91)90469-n

Giros, B., Sokoloff, P., Martres, M. P., Riou, J. F., Emorine, L. J., and Schwartz, J. C. (1989). Alternative splicing directs the expression of two D2 dopamine receptor isoforms. Nature 342, 923-926. doi: 10.1038/342923a0

Gold, S. J., Hoang, C. V., Potts, B. W., Porras, G., Pioli, E., Kim, K. W., et al. (2007). RGS9-2 negatively modulates L-3,4-dihydroxyphenylalanine-induced dyskinesia in experimental Parkinson's disease. J. Neurosci. 27, 14338-14348. doi: 10.1523/jneurosci.4223-07.2007

Greengard, P., Allen, P. B., and Nairn, A. C. (1999). Beyond the dopamine receptor: the DARPP-32/protein phosphatase-1 cascade. Neuron 23, 435-447. doi: 10.1016/S0896-6273(00)80798-9

Groman, S. M., Smith, N. J., Petrullli, J. R., Massi, B., Chen, L., Ropchan, J., et al. (2016). Dopamine D3 receptor availability is associated with inflexible decision making. J. Neurosci. 36, 6732-6741. doi: 10.1523/JNEUROSCI.325315.2016 
Gross, G., and Drescher, K. (2012). The role of dopamine $\mathrm{D}_{3}$ receptors in antipsychotic activity and cognitive functions. Handb. Exp. Pharmacol. 213, 167-210. doi: 10.1007/978-3-642-25758-2_7

Guigoni, C., Doudnikoff, E., Li, Q., Bloch, B., and Bezard, E. (2007). Altered $\mathrm{D}(1)$ dopamine receptor trafficking in parkinsonian and dyskinetic non-human primates. Neurobiol. Dis. 26, 452-463. doi: 10.1016/j.nbd.2007.02.001

Gulledge, A. T., and Jaffe, D. B. (1998). Dopamine decreases the excitability of layer $\mathrm{V}$ pyramidal cells in the rat prefrontal cortex. J. Neurosci. 18, 9139-9151.

Gurevich, E. V., Bordelon, Y., Shapiro, R. M., Arnold, S. E., Gur, R. E., and Joyce, J. N. (1997). Mesolimbic dopamine D3 receptors and use of antipsychotics in patients with schizophrenia. A postmortem study. Arch. Gen. Psychiatry 54, 225-232. doi: 10.1001/archpsyc.1997.01830150047009

Haber, S. N. (2014). The place of dopamine in the cortico-basal ganglia circuit. Neuroscience 282, 248-257. doi: 10.1016/j.neuroscience.2014.10.008

Hansen, N., and Manahan-Vaughan, D. (2014). Dopamine D1/D5 receptors mediate informational saliency that promotes persistent hippocampal long-term plasticity. Cereb. Cortex 24, 845-858. doi: 10.1093/cercor/bhs362

Hikida, T., Kimura, K., Wada, N., Funabiki, K., and Nakanishi, S. (2010). Distinct roles of synaptic transmission in direct and indirect striatal pathways to reward and aversive behavior. Neuron 66, 896-907. doi: 10.1016/j.neuron.2010. 05.011

Hikida, T., Yawata, S., Yamaguchi, T., Danjo, T., Sasaoka, T., Wang, Y., et al. (2013). Pathway-specific modulation of nucleus accumbens in reward and aversive behavior via selective transmitter receptors. Proc. Natl. Acad. Sci. US A 110, 342-347. doi: 10.1073/pnas.1220358110

Hornykiewicz, O. (2001). Chemical neuroanatomy of the basal ganglia-normal and in Parkinson's disease. J. Chem. Neuroanat. 22, 3-12. doi: 10.1016/s08910618(01)00100-4

Howes, O. D., and Kapur, S. (2009). The dopamine hypothesis of schizophrenia: version III-the final common pathway. Schizophr. Bull. 35, 549-562. doi: 10.1093/schbul/sbp006

Hwu, H. G., Hong, C. J., Lee, Y. L., Lee, P. C., and Lee, S. F. (1998). Dopamine D4 receptor gene polymorphisms and neuroleptic response in schizophrenia. Biol. Psychiatry 44, 483-487. doi: 10.1016/s0006-3223(98)00134-6

Hyman, S. E., Malenka, R. C., and Nestler, E. J. (2006). Neural mechanisms of addiction: the role of reward-related learning and memory. Annu. Rev. Neurosci. 29, 565-598. doi: 10.1146/annurev.neuro.29.051605.113009

Ito, K., Haga, T., Lameh, J., and Sadée, W. (1999). Sequestration of dopamine D2 receptors depends on coexpression of G-protein-coupled receptor kinases 2 or 5. Eur. J. Biochem. 260, 112-119. doi: 10.1046/j.1432-1327.1999. 00125.x

Joyce, J. N., and Millan, M. J. (2005). Dopamine D3 receptor antagonists as therapeutic agents. Drug Discov. Today 10, 917-925. doi: 10.1016/s13596446(05)03491-4

Kelly, M. A., Rubinstein, M., Phillips, T. J., Lessov, C. N., Burkhart-Kasch, S., Zhang, G., et al. (1998). Locomotor activity in D2 dopamine receptor-deficient mice is determined by gene dosage, genetic background and developmental adaptations. J. Neurosci. 18, 3470-3479.

Kerr, J. N., and Wickens, J. R. (2001). Dopamine D-1/D-5 receptor activation is required for long-term potentiation in the rat neostriatum in vitro. J. Neurophysiol. 85, 117-124.

Kharkwal, G., Brami-Cherrier, K., Lizardi-Ortiz, J. E., Nelson, A. B., Ramos, M., Del Barrio, D., et al. (2016). Parkinsonism driven by antipsychotics originates from dopaminergic control of striatal cholinergic interneurons. Neuron 91, 67-78. doi: 10.1016/j.neuron.2016.06.014

Kovoor, A., Seyffarth, P., Ebert, J., Barghshoon, S., Chen, C. K., Schwarz, S., et al. (2005). D2 dopamine receptors colocalize regulator of G-protein signaling 9-2 (RGS9-2) via the RGS9 DEP domain and RGS9 knock-out mice develop dyskinesias associated with dopamine pathways. J. Neurosci. 25, 2157-2165. doi: 10.1523/jneurosci.2840-04.2005

Kravitz, A. V., Freeze, B. S., Parker, P. R. L., Kay, K., Thwin, M. T., Deisseroth, K., et al. (2010). Regulation of parkinsonian motor behaviours by optogenetic control of basal ganglia circuitry. Nature 466, 622-626. doi: 10.1038/nature09159

Kravitz, A. V., Tye, L. D., and Kreitzer, A. C. (2012). Distinct roles for direct and indirect pathway striatal neurons in reinforcement. Nat. Neurosci. 15, 816-818. doi: 10.1038/nn.3100

Lacey, M. G., Mercuri, N. B., and North, R. A. (1987). Dopamine acts on $\mathrm{D} 2$ receptors to increase potassium conductance in neurones of the rat substantia nigra zona compacta. J. Physiol. 392, 397-416. doi: 10.1113/jphysiol. 1987.sp016787

Laruelle, M., Kegeles, L. S., and Abi-Dargham, A. (2003). Glutamate, dopamine and schizophrenia: from pathophysiology to treatment. Ann. N Y Acad. Sci. 1003, 138-158. doi: 10.1196/annals.1300.063

Lee, S. P., So, C. H., Rashid, A. J., Varghese, G., Cheng, R., Lan๔, A. J., et al. (2004). Dopamine D1 and D2 receptor Co-activation generates a novel phospholipase C-mediated calcium signal. J. Biol. Chem. 279, 35671-35678. doi: 10.1074/jbc. m401923200

Leggio, G. M., Bucolo, C., Platania, C. B., Salomone, S., and Drago, F. (2016). Current drug treatments targeting dopamine D3 receptor. Pharmacol. Ther. 165, 164-177. doi: 10.1016/j.pharmthera.2016.06.007

Lerner, T. N., and Kreitzer, A. C. (2012). RGS4 is required for dopaminergic control of striatal LTD and susceptibility to parkinsonian motor deficits. Neuron 73, 347-359. doi: 10.1016/j.neuron.2011.11.015

Loiseau, F., and Millan, M. J. (2009). Blockade of dopamine $\mathrm{D}_{3}$ receptors in frontal cortex, but not in sub-cortical structures, enhances social recognition in rats: similar actions of $\mathrm{D}_{1}$ receptor agonists, but not of $\mathrm{D}_{2}$ antagonists. Eur. Neuropsychopharmacol. 19, 23-33. doi: 10.1016/j.euroneuro.2008. 07.012

Mango, D., Bonito-Oliva, A., Ledonne, A., Cappellacci, L., Petrelli, R., Nisticò, R., et al. (2014a). Adenosine A1 receptor stimulation reduces D1 receptormediated GABAergic transmission from striato-nigral terminals and attenuates 1-DOPA-induced dyskinesia in dopamine-denervated mice. Exp. Neurol. 261, 733-743. doi: 10.1016/j.expneurol.2014.08.022

Mango, D., Bonito-Oliva, A., Ledonne, A., Nisticò, R., Castelli, V., Giorgi, M., et al. (2014b). Phosphodiesterase 10A controls D1-mediated facilitation of GABA release from striato-nigral projections under normal and dopamine-depleted conditions. Neuropharmacology 76, 127-136. doi: 10.1016/j.neuropharm.2013. 08.010

Martinez, D., Slifstein, M., Narendran, R., Foltin, R. W., Broft, A., Hwang, D. R., et al. (2009). Dopamine D1 receptors in cocaine dependence measured with PET and the choice to self-administer cocaine. Neuropsychopharmacology 34, 1774-1782. doi: 10.1038/npp.2008.235

Maurice, N., Tkatch, T., Meisler, M., Sprunger, L. K., and Surmeier, D. J. (2001). D1/D5 dopamine receptor activation differentially modulates rapidly inactivating and persistent sodium currents in prefrontal cortex pyramidal neurons. J. Neurosci. 21, 2268-2277.

De Mei, C., Ramos, M., Iitaka, C., and Borrelli, E. (2009). Getting specialized: presynaptic and postsynaptic dopamine D2 receptors. Curr. Opin. Pharmacol. 9, 53-58. doi: 10.1016/j.coph.2008.12.002

Mercuri, N. B., Saiardi, A., Bonci, A., Picetti, R., Calabresi, P., Bernardi, G., et al. (1997). Loss of autoreceptor function in dopaminergic neurons from dopamine D2 receptor deficient mice. Neuroscience 79, 323-327.

Min, C., Cheong, S. Y., Cheong, S. J., Kim, M., Cho, D. I., and Kim, K. M. (2012). RGS4 exerts inhibitory activities on the signaling of dopamine D2 receptor and D3 receptor through the N-terminal region. Pharmacol. Res. 65, 213-220. doi: $10.1016 /$ j.phrs.2011.08.008

Missale, C., Nash, S. R., Robinson, S. W., Jaber, M., and Caron, M. G. (1998). Dopamine receptors: from structure to function. Physiol. Rev. 78, 189-225.

Nakajima, S., Gerretsen, P., Takeuchi, H., Caravaggio, F., Chow, T., Le Foll, B., et al. (2013). The potential role of dopamine $\mathrm{D}_{3}$ receptor neurotransmission in cognition. Eur. Neuropsychopharmacol. 23, 799-813. doi: 10.1016/j.euroneuro. 2013.05.006

Napolitano, M., Centonze, D., Calce, A., Picconi, B., Spiezia, S., Gulino, A., et al. (2002). Experimental parkinsonism modulates multiple genes involved in the transduction of dopaminergic signals in the striatum. Neurobiol. Dis. 10, 387-395. doi: 10.1006/nbdi.2002.0525

Nikolaus, S., Antke, C., and Müller, H. W. (2009). in vivo imaging of synaptic function in the central nervous system: II. Mental and affective disorders. Behav. Brain Res. 204, 32-66. doi: 10.1016/j.bbr.2009.06.009

Oak, J. N., Oldenhof, J., and Van Tol, H. H. (2000). The dopamine $\mathrm{D}_{4}$ receptor: one decade of research. Eur. J. Pharmacol. 405, 303-327. doi: 10.1016/s00142999(00)00562-8

Okubo, Y., Suhara, T., Suzuki, K., Kobayashi, K., Inoue, O., Terasaki, O., et al. (1997). Decreased prefrontal dopamine D1 receptors in schizophrenia revealed by PET. Nature 385, 634-636. doi: 10.1038/385634a0

Packard, M. G., and White, N. M. (1991). Dissociation of hippocampus and caudate nucleus memory systems by post training intracerebral injection of 
dopamine agonists. Behav. Neurosci. 105, 295-306. doi: 10.1037/0735-7044. 105.2.295

Park, S. M., Chen, M., Schmerberg, C. M., Dulman, R. S., Rodriguiz, R. M., Caron, M. G., et al. (2016). Effects of $\beta$-arrestin-biased dopamine D2 receptor ligands on schizophrenia-like behavior in hypoglutamatergic mice. Neuropsychopharmacology 41, 704-715. doi: 10.1038/npp.2015.196

Pavón, N., Martin, A. B., Mendialdua, A., and Moratalla, R. (2006). ERK phosphorylation and FosB expression are associated with L-DOPA-induced dyskinesia in hemiparkinsonian mice. Biol. Psychiatry 59, 64-74. doi: 10.1016/j. biopsych.2005.05.044

Perez-Costas, E., Melendez-Ferro, M., and Roberts, R. C. (2010). Basal ganglia pathology in schizophrenia: dopamine connections and anomalies. J. Neurochem. 113, 287-302. doi: 10.1111/j.1471-4159.2010.06604.x

Perreault, M. L., Fan, T., Alijaniaram, M., O’Dowd, B. F., and George, S. R. (2012). Dopamine D1-D2 receptor heteromer in dual phenotype GABA/glutamatecoexpressing striatal medium spiny neurons: regulation of BDNF, GAD67 and VGLUT1/2. PLoS One 7:e33348. doi: 10.1371/journal.pone.0033348

Perreault, M. L., Hasbi, A., O’Dowd, B. F., and George, S. R. (2014). Heteromeric dopamine receptor signaling complexes: emerging neurobiology and disease relevance. Neuropsychopharmacology 39, 156-168. doi: 10.1038/npp.2013.148

Picconi, B., Centonze, D., Håkansson, K., Bernardi, G., Greengard, P., Fisone, G., et al. (2003). Loss of bidirectional striatal synaptic plasticity in L-DOPAinduced dyskinesia. Nat. Neurosci. 6, 501-506. doi: 10.1038/nn1040

Powell, S. B., Paulus, M. P., Hartman, D. S., Godel, T., and Geyer, M. A. (2003). RO-10-5824 is a selective dopamine D4 receptor agonist that increases novel object exploration in C57 mice. Neuropharmacology 44, 473-481. doi: 10.1016/s0028-3908(02)00412-4

Prieto, G. A., Perez-Burgos, A., Palomero-Rivero, M., Galarraga, E., DruckerColin, R., and Bargas, J. (2011). Upregulation of D2-class signaling in dopamine-denervated striatum is in part mediated by D3 receptors acting on Ca V 2.1 channels via PIP2 depletion. J. Neurophysiol. 105, 2260-2274. doi: $10.1152 /$ jn.00516.2010

Ptáček, R., Kuželová, H., and Stefano, G. B. (2011). Dopamine D4 receptor gene DRD4 and its association with psychiatric disorders. Med. Sci. Monit. 17, RA215-RA220. doi: 10.12659/msm.881925

Puig, M. V., and Miller, E. K. (2015). Neural substrates of dopamine d2 receptor modulated executive functions in the monkey prefrontal cortex. Cereb. Cortex 25, 2980-2987. doi: 10.1093/cercor/bhu096

Ragozzino, M. E. (2002). The effects of dopamine D1 receptor blockade on the prelimbic-infralimbic areas on behavioral flexibility. Learn. Mem. 9, 18-28. doi: $10.1101 / \mathrm{lm} .45802$

Rahman, Z., Schwarz, J., Gold, S. J., Zachariou, V., Wein, M. N., Choi, K. H., et al. (2003). RGS9 modulates dopamine signaling in the basal ganglia. Neuron 38, 941-952. doi: 10.1016/s0896-6273(03)00321-0

Reavill, C., Taylor, S. G., Wood, M. D., Ashmeade, T., Austin, N. E., Avenell, K. Y., et al. (2000). Pharmacological actions of a novel, high-affinity and selective human dopamine $\mathrm{D}(3)$ receptor antagonist, SB-277011-A. J. Pharmacol. Exp. Ther. 294, 1154-1165.

Rocchetti, J., Isingrini, E., Dal Bo, G., Sagheby, S., Menegaux, A., Tronche, F., et al. (2015). Presynaptic D2 dopamine receptors control long-term depression expression and memory processes in the temporal hippocampus. Biol. Psychiatry 77, 513-525. doi: 10.1016/j.biopsych.2014.03.013

Rubinstein, M., Phillips, T. J., Bunzow, J. R., Falzone, T. L., Dziewczapolski, G., Zhang, G., et al. (1997). Mice lacking dopamine D4 receptors are supersensitive to ethanol, cocaine and methamphetamine. Cell 90, 991-1001. doi: 10.1016/s0092-8674(00)80365-7

Santini, E., Valjent, E., Usiello, A., Carta, M., Borgkvist, A., Girault, J. A., et al. (2007). Critical involvement of cAMP/DARPP-32 and extracellular signalregulated protein kinase signaling in L-DOPA-induced dyskinesia. J. Neurosci. 27, 6995-7005. doi: 10.1523/JNEUROSCI.0852-07.2007

Sawaguchi, T., and Goldman-Rakic, P. S. (1991). D1 dopamine receptors in prefrontal cortex: involvement in working memory. Science 251, 947-950. doi: $10.1126 /$ science. 1825731

Schultz, W. (2002). Getting formal with dopamine and reward. Neuron 36, 241-263. doi: 10.1016/s0896-6273(02)00967-4

Schultz, W., Dayan, P., and Montague, P. R. (1997). A neural substrate of prediction and reward. Science 275, 1593-1599. doi: 10.1126/science.275. 5306.1593
Seamans, J. K., and Yang, C. R. (2004). The principal features and mechanisms of dopamine modulation in the prefrontal cortex. Prog. Neurobiol. 74, 1-58. doi: 10.1016/j.pneurobio.2004.05.006

Seeman, P. (2011). All roads to schizophrenia lead to dopamine supersensitivity and elevated dopamine D2(high) receptors. CNS Neurosci. Ther. 17, 118-132. doi: $10.1111 / j .1755-5949.2010 .00162 . x$

Seeman, P., Guan, H. C., and Van Tol, H. H. (1993). Dopamine D4 receptors elevated in schizophrenia. Nature 365, 441-445. doi: 10.1038/365441a0

Seeman, P., Ko, F., Jack, E., Greenstein, R., and Dean, B. (2007). Consistent with dopamine supersensitivity, RGS9 expression is diminished in the amphetamine-treated animal model of schizophrenia and in postmortem schizophrenia brain. Synapse 61, 303-309. doi: 10.1002/syn. 20368

Seeman, P., Weinshenker, D., Quirion, R., Srivastava, L. K., Bhardwaj, S. K., Grandy, D. K., et al. (2005). Dopamine supersensitivity correlates with D2 High states, implying many paths to psychosis. Proc. Natl. Acad. Sci. U S A 102, 3513-3518. doi: 10.1073/pnas.0409766102

Self, D. W. (2010). "Dopamine receptor subtypes in reward and relapse," in The Dopamine Receptors, 2nd Edn. ed. K. A. Neve (New York, NY: Humana Press), 479-524.

da Silva Lobo, D. S., Vallada, H. P., Knight, J., Martins, S. S., Tavares, H., Gentil, V., et al. (2007). Dopamine genes and pathological gambling in discordant sib-pairs. J. Gambl. Stud. 23, 421-433. doi: 10.1007/s10899-0079060-x

Silveira, P. P., Portella, A. K., Kennedy, J. L., Gaudreau, H., Davis, C., Steiner, M., et al. (2014). Association between the seven-repeat allele of the dopamine-4 receptor gene (DRD4) and spontaneous food intake in pre-school children. Appetite 73, 15-22. doi: 10.1016/j.appet.2013.10.004

Sokoloff, P., and Le Foll, B. (2017). The dopamine D3 receptor, a quarter century later. Eur. J. Neurosci. 45, 2-19. doi: 10.1111/ejn.13390

Stelzel, C., Fiebach, C. J., Cools, R., Tafazoli, S., and D’Esposito, M. (2013). Dissociable fronto-striatal effects of dopamine D2 receptor stimulation on cognitive versus motor flexibility. Cortex 49, 2799-2811. doi: 10.1016/j.cortex. 2013.04.002

Steinberg, E. E., Boivin, J. R., Saunders, B. T., Witten, I. B., Deisseroth, K., and Janak, P. H. (2014). Positive reinforcement mediated by midbrain dopamine neurons requires D1 and D2 receptor activation in the nucleus accumbens. PLoS One 9:e94771. doi: 10.1371/journal.pone.0094771

Sun, H., Calipari, E. S., Beveridge, T. J. R., Jones, S. R., and Chen, R. (2015). The Brain gene expression profile of dopamine D2/D3 receptors and associated signaling proteins following amphetamine self-administration. Neuroscience 307, 253-261. doi: 10.1016/j.neuroscience.2015.08.053

Thanos, P. K., Bermeo, C., Rubinstein, M., Suchland, K. L., Wang, G. J., Grandy, D. K., et al. (2010). Conditioned place preference and locomotor activity in response to methylphenidate, amphetamine and cocaine in mice lacking dopamine D4 receptors. J. Psychopharmacol. 24, 897-904. doi: $10.1177 / 0269881109102613$

Tiberi, M., Nash, S. R., Bertrand, L., Lefkowitz, R. J., and Caron, M. G. (1996). Differential regulation of dopamine D1A receptor responsiveness by various G protein-coupled receptor kinases. J. Biol. Chem. 271, 3771-3778. doi: $10.1074 / \mathrm{jbc} .271 .7 .3771$

Van Tol, H. H., Wu, C. M., Guan, H. C., Ohara, K., Bunzow, J. R., Civelli, O., et al. (1992). Multiple dopamine D4 receptor variants in the human population. Nature 358, 149-152. doi: 10.1038/358149a0

Traynor, J. R., Terzi, D., Caldarone, B. J., and Zachariou, V. (2009). RGS9-2: probing an intracellular modulator of behavior as a drug target. Trends Pharmacol. Sci. 30, 105-111. doi: 10.1016/j.tips.2008.11.006

Urs, N. M., Daigle, T. L., and Caron, M. G. (2011). A dopamine D1 receptor-dependent $\beta$-arrestin signaling complex potentially regulates morphine-induced psychomotor activation but not reward in mice. Neuropsychopharmacology 36, 551-558. doi: 10.1038/npp.2010.186

Usiello, A., Baik, J. H., Rougé-Pont, F., Picetti, R., Dierich, A., LeMeur, M., et al. (2000). Distinct functions of the two isoforms of dopamine D2 receptors. Nature 408, 199-203. doi: 10.1038/35041572

Villar, V. A., Jones, J. E., Armando, I., Palmes-Saloma, C., Yu, P., Pascua, A. M., et al. (2009). G protein-coupled receptor kinase 4 (GRK4) regulates the phosphorylation and function of the dopamine D3 receptor. J. Biol. Chem. 284, 21425-21434. doi: 10.1074/jbc.M109.003665 
Volkow, N. D., Chang, L., Wang, G. J., Fowler, J. S., Ding, Y. S., Sedler, M., et al. (2001). Low level of brain dopamine D2 receptors in methamphetamine abusers: association with metabolism in the orbitofrontal cortex. Am. J. Psychiatry 158, 2015-2021. doi: 10.1176/appi.ajp.158.12.2015

Volkow, N. D., Fowler, J. S., Wang, G. J., Hitzemann, R., Logan, J., Schlyer, D. J., et al. (1993). Decreased dopamine D2 receptor availability is associated with reduced frontal metabolism in cocaine abusers. Synapse 14, 169-177. doi: 10.1002/syn.890140210

Volkow, N. D., and Morales, M. (2015). The brain on drugs: from reward to addiction. Cell 162, 712-725. doi: 10.1016/j.cell.2015.07.046

Volkow, N. D., Wang, G. J., Fowler, J. S., Logan, J., Hitzemann, R., Ding, Y. S., et al. (1996). Decreases in dopamine receptors but not in dopamine transporters in alcoholics. Alcohol. Clin. Exp. Res. 20, 1594-1598. doi: 10.1111/j.1530-0277. 1996.tb05936.x

Wang, Y., and Goldman-Rakic, P. S. (2004). D2 receptor regulation of synaptic burst firing in prefrontal cortical pyramidal neurons. Proc. Natl. Acad. Sci. U S A 101, 5093-5098. doi: 10.1073/pnas.0400954101

Wang, Y., Xu, R., Sasaoka, T., Tonegawa, S., Kung, M. P., and Sankoorikal, E. B. (2000). Dopamine D2 long receptor-deficient mice display alterations in striatum-dependent functions. J. Neurosci. 20, 8305-8314.

Wani, K. A., Catanese, M., Normantowicz, R., Herd, M., Maher, K. N., and Chase, D. L. (2012). D1 dopamine receptor signaling is modulated by the R7 RGS protein EAT-16 and the R7 binding protein RSBP-1 in Caenoerhabditis elegans motor neurons. PLoS One 7:e37831. doi: 10.1371/journal.pone.00 37831

Watanabe, H., Xu, J., Bengra, C., Jose, P. A., and Felder, R. A. (2002). Desensitization of human renalD1dopaminereceptorsby $G$ protein-coupled receptor kinase 4. Kidney Int. 62, 790-798. doi: 10.1046/j.1523-1755.2002. 00525.x

Weinstein, J. J., Chohan, M. O., Slifstein, M., Kegeles, L. S., Moore, H., and Abi-Dargham, A. (2017). Pathway-specific dopamine abnormalities in schizophrenia. Biol. Psychiatry 81, 31-42. doi: 10.1016/j.biopsych.2016.03.2104

Wise, R. A. (2009). Roles for nigrostriatal—not just mesocorticolimbic_dopamine in reward and addiction. Trends Neurosci. 32, 517-524. doi: 10.1016/j.tins.2009. 06.004
Witkowski, G., Szulczyk, B., Rola, R., and Szulczyk, P. (2008). D1 dopaminergic control of $\mathrm{G}$ protein-dependent inward rectifier $\mathrm{K}^{+}$(GIRK)-like channel current in pyramidal neurons of the medial prefrontal cortex. Neuroscience 155, 53-63. doi: 10.1016/j.neuroscience.2008.05.021

Wolf, M. E., and Roth, R. H. (1990). Autoreceptor regulation of dopamine synthesis. Ann. N Y Acad. Sci. 604, 323-343. doi: 10.1111/j.1749-6632.1990. tb32003.x

Woolley, M. L., Waters, K. A., Reavill, C., Bull, S., Lacroix, L. P., Martyn, A. J., et al. (2008). Selective dopamine D4 receptor agonist (A-412997) improves cognitive performance and stimulates motor activity without influencing rewardrelated behaviour in rat. Behav. Pharmacol. 19, 765-776. doi: 10.1097/FBP. 0b013e32831c3b06

$\mathrm{Xu}$, M. (1998). Unraveling dopamine D3 receptor function in response to psychostimulants using a genetic approach. Ann. N Y Acad. Sci. 844, 27-39. doi: 10.1111/j.1749-6632.1998.tb08219.x

Yang, J., Ye, M., Tian, C., Yang, M., Wang, Y., and Shu, Y. (2013). Dopaminergic modulation of axonal potassium channels and action potential waveform in pyramidal neurons of prefrontal cortex. J. Physiol. 591, 3233-3251. doi: 10.1113/jphysiol.2013.251058

Yoon, J. H., Minzenberg, M. J., Raouf, S., D’Esposito, M., and Carter, C. S. (2013). Impaired prefrontal-basal ganglia functional connectivity and substantia nigra hyperactivity in schizophrenia. Biol. Psychiatry 74, 122-129. doi: 10.1016/j. biopsych.2012.11.018

Conflict of Interest Statement: The authors declare that the research was conducted in the absence of any commercial or financial relationships that could be construed as a potential conflict of interest.

Copyright (ㄷ) 2017 Ledonne and Mercuri. This is an open-access article distributed under the terms of the Creative Commons Attribution License (CC BY). The use, distribution and reproduction in other forums is permitted, provided the original author(s) or licensor are credited and that the original publication in this journal is cited, in accordance with accepted academic practice. No use, distribution or reproduction is permitted which does not comply with these terms. 